\title{
Multilingual Communication Space in English Translations of Boris Akunin's Texts
}

\author{
Viktoriya N. Karpukhina* \\ Altai State University \\ 61 Lenina, Barnaul, 656049, Russia
}

Received 10.01.2017, received in revised form 18.12.2017, accepted 09.01.2018

\begin{abstract}
The article considers changes of communication space in the era of globalization. These changes are analyzed in the postmodern fiction text translation. Multilingual communication space in the Boris Akunin's novel of "Azazel"' translated into English by Andrew Bromfield differs from the type of the communication space in the source text. It deals with the main axiological linguistic macrostrategy used by the translator that is the adaptation macrostrategy. Adaptation macrostrategy shows the diversity of the semantic category of space, textual and cultural alike, in cross-cultural communication. Bipolarity of this macrostrategy (adaptation / foreigning) is caused by translator's necessity either to acculturate a source text into the culture of a target text, or, vice versa, to make an effect of estrangement of a target text. As a result of this macrostrategy usage, some functions of multilingual communication space of the source text are lost in translation, and the English language loses its role of 'lingua franca' in the global communication space.
\end{abstract}

Keywords: communication space, English, Russian, communication fragment, fiction text, translation.

DOI: 10.17516/1997-1370-0208.

Research area: philology.

\section{Introduction}

International culture globalization results in forming of a new type of communication space. On the one side, this communication space lets people go over many borders: those of language, culture, and national customs and traditions. On the other side, forming of the global communication space leads to changes in the traditional system of intracultural communication. This, in turn, effects in destroying of local cultures. It is true that "the semiosphere borders are the hottest spots' of semiosis" (Lotman, 2000: 262). But some researchers consider the contemporary communication space to be different from that type of semiosphere Yury M. Lotman mentioned in his works. "Semiosphere supposed cultures differed from each other, and this was the pre-condition for them to communicate. The contemporary communication space, on the contrary, creates new rules and means of communication, making cultures use this 'language'. ...The pseudo-cultural field of communication widen, and the dialogue in it goes with the principle of acknowledgement of the most available and almost always similar contents. This communication field is ruled

(c) Siberian Federal University. All rights reserved

* Corresponding author E-mail address: vkarpuhina@yandex.ru 
by common stereotypes, common behavior parameters, the simplest compounds of common access" (Mironov, 2006: 36).

Encyclopedic knowledge, necessary for participants of cross-cultural communication, turns into specific verbal and non-verbal stereotypes and clichés, successively. Strategic manipulating with stereotypical plots and characters of a traditional detective narration becomes both the object of a narrator's irony and means of a comic effect making in the "ironic detective stories" by Boris Akunin. Classical and neoclassical British detective narratives appear to be the material for construing of a new communicative space in a contemporary detective story (Karpukhina, 2015: 10).

The article considers Boris Akunin's novel of Azazel' (Akunin, 2001) and its translation into English The Winter Queen, made by A. Bromfield (Akunin, 2012). The article deals with communication space characteristics of the mentioned source and target texts. The aims of the article are: 1) to analyze functions of foreign language communicative fragments in discourses of Azazel' characters and 2) to assess equivalents of those fragments and their functions in the target text in English.

The time characteristics of Boris Akunin's texts were analyzed in many research works (Desyatov, 2009, 2010; Desyatov, Karpukhina, 2014; Karpukhina, 2003a, 2003b, 2010a, 2003b, 2011, 2014, 2015; Ranchin, 2013; Krivousova, 2014). Boris Akunin uses axiological macrostrategy of archaization in his "historic detective narratives" to diverse the time characteristics of textual chronotopes. This macrostrategy effects in diversity of semantic category of time - textual and cultural alike. Text archaization macrostrategy could be appreciated, for example, on the level of a plot construing: source text frame includes propositions of assessment, which have an effect on further text translations. But the space characteristics of Boris Akunin's texts were not under detailed academic consideration yet. Especially it is true when the characteristics of communication space in Boris Akunin's novels, translated into English, are under the consideration.

\section{Multilingual Communication \\ Space}

Communication space of one of the most famous Boris Akunin's novels, Azazel', is multilingual. Communicative fragments of different languages mark national identity of a character and different cultural borders in the text. Discourses of Azazel' characters include communicative fragments in foreign languages, which are not equal to idioms or clichés. These foreign languages communicative fragments could represent text means, which allow the author set on cognitive features of text characters. These cognitive features could be reconstructed by an interpreter of the text.

These cognitive characteristics differ national and cultural bits of language information in all-Russian linguistic type of linguistic identity, on the semantic level of its structure. They work in the same way "on the highest motivational level of a linguistic identity structure, which determines national and cultural motivation of discourse behavior" (Karaulov, 2002: 42). Communicative fragments in foreign languages, included into a character's discourse, allow us to estimate such cognitive characteristics as memory, good or bad command in a foreign language, and ability to understand a foreign conversation partner. In other words, analyzing communicative fragments in foreign languages, which are included into a text character's discourse, we reveal characters' cognitive features, which affect their communicative potential in their native and foreign communication space. 


\section{Functions of Foreign Languages \\ Communicative Fragments \\ in Boris Akunin's Azazel' and its Translation into English}

Most of the Azazel' characters use foreign languages communicative fragments in their discourses. We suppose they have multilingual conscience. Boris M. Gasparov says, "multilingual conscience is an integrated conglomerate of language memory, in which the language substance particles, belonged to different languages, and their associative fields links "drift" easily, making new connections and new configurations" (Gasparov, 1996: 112). Communicative fragments, extracted by the Azazel' characters from their multilingual conscience, are diverse. It allows the author to present such a cognitive and communicative characteristic of a person as his / her command in foreign languages. For example, Erast Fandorin, the main character of Azazel', speaks English well (Разговора на английском Эраст Петрович не боялся (Akunin, 2001: 109) - Erast Fandorin was not afraid of conversing in English (Akunin, 2012); «У вас славное произночение, сэр», похвалила леди Эстер на том же языке (Akunin, 2001: 109). - «Your pronunciation is splendid, sir,» Lady Astair praised him in the same language (Akunin, 2012)). Communicative fragments of his discourse are given in the source text of the novel in English with their translations into Russian as the commentaries at the bottom of a page.

It is worth saying that the author only marks the foreign languages space with the first phrase of a conversation, but the conversation itself goes in Russian. We can compare to it the similar strategy of Leo Tolstoy, analyzed in Yury M. Lotman's work: "It is illustrative enough that Leo Tolstoy in his War and Peace gives many examples of French speech for represent the speech of Russian noblemen. In those parts he wants to represent the speech of the French, he gives it in Russian. The French language is given there only in the first words as a marker of language space or a characteristic of French mentality" (Lotman, 2000: 65). Azazel' by Boris Akunin represents another international language for multilingual space of Russia. It is English but not French, as it were in Leo Tolstoy's War and Peace. So, it can be said that the universal language of culture is changed.

When these communication fragments in foreign languages of Azazel' are translated into English, the "text in the text" is lost, on the one side. On the other side, English as a marker of cross-cultural communication disappears from the target text: - Третьего отделения чиновник Фандорин, по срочному делу, - строго сказал Эраст Петрович, однако лочадиная физиономия лакея осталась непроницаемой, и пришлось пояснить по-английски: - State police, Inspector Fandorin, on urgent official business (Akunin, 2001: 283). - «Fandorin, officer of the Third Section, on urgent business,» Erast Fandorin announced austerely. However, the lackey's equine features remained impassive, and Fandorin was obliged to explain in English. «State police, Inspector Fandorin, on urgent official business» (Akunin, 2012).

The translator of many works by Boris Akunin into English is Andrew Bromfield, the founder of GLAS magazine, which aims to popularize Russian literature abroad, in Englishspeaking countries. The main axiological linguistic macrostrategy of Bromfield, the translator of Alexander Pushkin, Mikhail Bulgakov, Leo Tolstoy, Viktor Pelevin, Boris Akunin, Vladimir Voinovich, Sergey Luk'yanenko, etc. into English, is macrostrategy of text adaptation. We suppose that using of this macrostrategy allows Bromfield to remain one of the most acknowledged translators of Russian literature in demand. 
Adaptation macrostrategy shows the diversity of the semantic category of space, text and cultural alike, in cross-cultural communication. Bipolarity of this macrostrategy (adaptation / foreigning) is caused by translator's necessity of either acculturation of a source text into the culture of a target text, or, vice versa, making an effect of "estrangement" of a target text (Karpuhina, 2013). Text adaptation "may be understood as a set of translative operations which result in a text which is not accepted as a translation but it is nevertheless recognized as representing of source text of about the same length" (Routledge Encyclopedia..., 1998: 5). Moreover, adaptation may be viewed "as a 'reterritorialization' of the original work and an 'annexation' in the name of the audience of the new version" (Routledge Encyclopedia..., 1998: 6).

Macrostrategy of adaptation, used by Andrew Bromfield in Russian-English translations of literary texts, allows him to vary even the titles of source texts, offering either equivalent translation versions of the titles of Boris Akunin's novels to a Western reader ("Смерть Ахиллеса» - The Death of Achilles, «Алмазная колесница»-The Diamond Chariot), or free adapted versions, connected only to the plot of Akunin's works («Азазель» - The Winter Queen). The English title of the target novel (The Winter Queen) is linked to the plot in its setting: the hotel Winter Queen, where the femme fatale Amalia Bezhetskaya lives in London, is one of the most important locations of the novel (Akunin, 2001: 142). Another association with this words combination is the fairy-tale of The Snow Queen by Hans Christian Andersen. This metaphorical association (the Winter Queen - the Snow Queen) is linked to the main malicious character in the novel, lady Ester. The fairy-tale association goes even deeper into mythology, because Andrew Bromfield decides to transpose the first name of the main heroine as Astair, which is very close to the name of the goddess Astarte.

The intrusion of foreign languages communicative fragments into the text of the novel generates new implications. Erast Fandorin hears that Amalia Bezhetskaya speaks excellent English to Morbid, and concludes that she is a spy (Akunin, 2001: 166). So, the cognitive characteristic of a good command in a foreign language, which strengthens the communicative potential of novel's characters, allows us to see social and 'professional' status of characters. Using foreign languages communicative fragments in the discourse of the novel's character, together with the ironical commentary of a narrator, reveals some psychological features of a character.

The hot-tempered count Hippolyte Zurov, for example, speaks French very well: Граф насмешливо вставил, картавя на истинно парижский манер: «J'en ai le frisson que d'y penser» (Akunin, 2001: 68). - Rolling his $\boldsymbol{r}$ like a true Parisian, the count interjected: «J'en ai le frisson que d'y penser» (Akunin, 2012). But, at the same time, he can say being extremely irritated to his conversation partners: «Извольте-ка не франиузить! Что, право, за дурачкая привычка втыкать в русскую речь по пол франиузской фразки» (Akunin, 2001: 129). - «Be so kind as not to Frenchify. It really is a stupid habit to stick half of a French phrase into Russian speech» (Akunin, 2012). Communicative fragments of French are transposed by Andrew Bromfield into The Winter Queen in an adequate way.

Boris Akunin invents a very successful strategy showing a character's bad command in a foreign language. This strategy is applied when the foreign language communicative fragments are given in the text in Cyrillic script: «Из полиции, Фандорин. Bы госпожа Пфуль? - неуверенно произнес Эраст 
Петрович и на всякий случай повторил понемецки. - Полицайамт. Зинд зи фрейляйн Пфуль? Гутен абенд» (Akunin, 2001: 46). Two English phrases, used by Hippolyte Zurov in London, are represented in Cyrillic script, too. This conventionality in representing of foreign languages communication fragments allows a reader to see the level of a character's linguistic abilities. It also shows the development of a character's abilities in successful communication (...Erast Fandorin inquired uncertainly... (Akunin, 2012)).

Andrew Bromfield, while translating such fragments of the source text, can not follow the Boris Akunin's strategy: «I am from the police. My name is Fandorin. Are you Miss Pfühl?» Erast Fandorin inquired uncertainly, then repeated the question in German just to be sure: «Polizeiamt. Sind Sie Freilein Pfühl? Guten Abend» (Akunin, 2012). He just translates the communication fragment into German properly.

Interlingual transfer, often a phonetic one ("surface-located, but the brightest evidence of a foreign speaker phrase for a Russian reader" (Karaulov, 2002: 144)), is used in the novel to add comical features to some characters' pictures. Speech characteristic of a person turns into a psychological one: «Клоун! Пшют гороховый! прошипела храбрая немка, обнаруживая неплохое знание разговорной русской речи» (Akunin, 2001). - «You clown! You motley buvfoon!» whispered the valiant German matron, demonstrating a quite respectable knowledge of colloquial Russian (Akunin, 2012). The comical effect is created in the source text because of lexical and phonetic transfer of two language units, пиют and иут гороховыци. This wordplay game is not translated into English.

Andrew Bromfield uses many cases of phonetic transfer to represent German-Russian speech. He rejects Boris Akunin's strategy of playing onto lexical and grammar mistakes in a foreign language speaker's discourse: Да, я умею понимать чин, - кивнула немка, показывая пальцем на петлицу его вицумундира. - Итак, господин коллежский регистратор, я вас слушаю (Akunin, 2001: 47). - «Yes, I know how to understand rank,» the German woman said with a nod, pointing to the lapel of his uniform jacket. «Zo, mister collegiate registrar, I am listening» (Akunin, 2012). Lexical and grammar mistakes in a foreign language speaker's discourse, wrong usage of a modal verb (я умею понимать чин) are compensated with the help of phonetic transfer ( $z O$ instead of so). The same adaptation macrostrategy is used in the following fragment: - Bосnитаннье баронессы не бегают, аходят, - с притворной строгостью сказала ей гувернантка. Особенно если им уже ичельх земнадцать лет. Если вы не бегаете, а ходите, у вас есть время, чтобы увидеть незнакомый человек и прилично поздороваться (Akunin, 2001: 47). - «Vell brought-up young baronesses do not run, zey valk,» her governess told her with feigned strictness. "Ezpecially ven zey are all of zeventeen years old. If you do not run but valk, zen you haf time to notice a stranger and greet him properly» (Akunin, 2012). Phonetic transfer is used in the source text, too: земнадияать instead of семнадиать. This phonetic transfer has its absolute equivalent in the target text (zeventeen). But lack of the conjugated forms of the adjective and the noun in the Object Case (увидеть незнакомый человек) is not represented in the target text. The compensation works as a mass intrusion of phonetic transfers in English speech of a German (vell, ezpecially, ven, zey, haf). Adaptation macrostrategy in the English translation of Boris Akunin's text emphasizes phonetic transfers in the discourses of non-English speakers. Their mistakes in lexis and grammar are out of the translator's strategic interest. 
In some cases, Andrew Bromfield uses adaptation macrostrategy while eliminating bits of information from the source text. For example, if there are errors in Russian historical realities in the source text Andrew Bromfield eliminates this text fragment. He keeps to the historically correct information, for example: Да, я умею понимать чин, - кивнула немка, показывая пальцем на петлицу его вицмундира. - Итак, господин коллежский регистратор, я вас слушаю (Akunin, 2001: 47). - «Yes, I know how to understand rank,» the German woman said with a nod, pointing to the lapel of his uniform jacket. "Zo, mister collegiate registrar, I am listening» (Akunin, 2012). An everyday uniform jacket (вицмундир) is a civil servant's dress-suit, which is different from a smart uniform suit with no tabs on its lapel. The translator tactfully omits the details of Akunin's text with its error in Russian historical reality (показывая пальием на петлииу его виимундира), and gives only general information of the text fragment: pointing to the lapel of his uniform jacket. We can see there how free translation approaches to the faithful translation (using the terms of (Snell-Hornby, 1988: 26; Andrews, 2010: 11)). Free translation is pragmatically motivated there: the factual error of the source text does not come into the target text. It is adapted for the native English readers in its historically correct version.

\section{Conclusion}

The main translation macrostrategy used by Andrew Bromfield in his target text of The Winter
Queen is axiological linguistic macrostrategy of adaptation. He adapted mostly proper names and historical and cultural realities of the source text by Boris Akunin. The additional adaptation strategy is modernization: instead of obsolete lexical units there are used neutral contemporary words; there are many colloquial words and abbreviations, modernizing the target text. Factual mistakes made by Boris Akunin are eliminated from the target text. The translator provides the target text reader with accurate information in history and culture of Russia in the late $19^{\text {th }}-$ early $20^{\text {th }}$ centuries.

Multilingual communication space of the Azazel' novel by Boris Akunin goes through the language borders to exist in the target text version. But foreign languages communicative fragments in the discourses of multilingual characters in English translation are sometimes different from those in Russian. Andrew Bromfield represents rather phonetic than lexical or grammar transfer in discourses of foreign language speakers. In the source text, Boris Akunin uses all the means of language transfer to make a comic effect or show cognitive and communicative potential of foreign language speakers. Lack of linguistic abilities in foreign languages is represented in the source text with the help of English or German words written in Cyrillic script. The target text lacks this strategic technique. The English language, which is spoken by many characters of the Azazel' novel, is not an international language in the target text. In The Winter Queen English loses its function of lingua franca in the new era of communication.

\section{References}

Akunin, B. (2001). Azazel' [Azazel]. Moscow, «Zakharov», 2001, 335 p.

Akunin, B. (2012). The Winter Queen. Available at: http://biblioteka.cc/index.php?newsid=113298 (accessed 13 November 2012).

Andrews, E., Maksimova, E.A. (2010). Russian Translation: Theory and Practice. London, New York, Routledge, Taylor and Francis Group, 187 p. 
Baker, M. (ed.) (1998). Routledge Encyclopedia of Translation Studies. London, New York, Routledge, $654 \mathrm{p}$.

Desyatov, V.V. (2009). Liubov' Stiopkina: Boris Akunin i Vasilii Shukshin [Stiopka's love: Boris Akunin and Vasilii Shukshin], In Filologiia i chelovek [Philology and Person], 2, 45-52.

Desyatov, V.V. (2010). Russkii Bog (Boris Akunin i Vasilii Shukshin) [Russian God: Boris Akunin and Vasilii Shukshin], In Filologiia i chelovek [Philology and Person], 3, 109-121.

Desyatov, V.V., Karpukhina, V.N. (2014). Chto takoe khorosho i chto takoe plokho? O filosofskikh romanakh Borisa Akunina i Glorii Mu "Detskaia kniga", "Detskaya kniga dlia devochek" [What is good and what is bad? About philosophical novels "Children's book" and "Children's book for girls" by Boris Akunin and Gloria Mu], In Sibirskii filologicheskii zhurnal [Siberian Philological Journal], 1, 178-185.

Gasparov, B.M.(1996). Iazyk, pamiat', obraz. Lingvistika iazykovogo suschestvovaniia [Language, memory, image. Linguistics of language existence]. Moscow, Novoe literaturnoe obozrenie, 352 p.

Karaulov, Iu.N. (2002). Russkii iazyk i iazykovaia lichnost' [The Russian language and Russian linguistic identity]. Moscow, Editorial URSS, 264 p.

Karpukhina, V.N. (2003a). Modelirovanie kognitivnykh kharakteristik personazha khudozhestvennogo teksta [Modeling of cognitive features of a fiction text character], In Aktual'nye problemy rusistiki [Topical questions of Russian philology]. Tomsk, Izdatel'stvo Tomskogo universiteta, 2(1), 168-172.

Karpukhina, V.N. (2003b). Postroenie interteksta kak odin is sposobov tekstovoi interpretatsii [Construing of intertext as one of the ways of text interpretation], In Tekst: varianty interpretatsii [Text: versions of interpretation]. Biisk, Izdatel'stvo Biiskogo pedagogicheskogo universiteta, 102-104.

Karpukhina, V.N. (2010a). Prostranstvo mezhkul'turnoi kommunikatsii v tekstakh B. Akunina [Cross-cultural communication space in the texts of Boris Akunin], In Problemy mezhkul'turnoi kommunikatsii v teorii iazyka i lingvodidaktike [Problems of cross-cultural communication in linguistics and linguistic didactics]. Barnaul, Izdatel'stvo Altaiskoi pedagogicheskoi akademii, 271-275.

Karpukhina, V.N. (2010b). Khronotopicheskie kharakteristiki dvukh romanov Borisa Akunina [Chronotopical characteristics of two novels by Boris Akunin], In 21 vek: itogi proshlogo i problemy nastoiaschego [21st century: results of the past and questions of the present time]. Penza, Izdatel'stvo Penzenskoi tekhnicheskoi akademii, 159-161.

Karpukhina, V.N. (2011). Aksiologicheskie kharakteristiki khronotopa v tekstakh B. Akunina i Dzh. Faulza [Axiological characteristics of chronotope in the texts of Boris Akunin and John Fowles], In Problemy mezhtekstovykh sviazei: Sbornik nauchnykh statei [Problems of intertextual links]. Barnaul, Azbuka, 53-61.

Karpukhina, V.N. (2011). Transformatsii temporal'nykh kharakteristik tekstov khudozhestvennoi literatury $\mathrm{v}$ protsesse mezhkul'turnoi kommunikatsii [Transformations of fiction texts temporal characteristics in cross-cultural communication], In Sibirskii filologicheskii zhurnal [Siberian Philological Journal], 4, 213-220.

Karpukhina, V.N. (2013). Konstruirovanie lingvisticheskoi real'nosti pri smene semioticheskogo koda kul'tury [Construing of linguistic reality with semiotic cultural code change]. Barnaul, Izdatel'stvo Altaiskogo universiteta, $232 \mathrm{p}$. 
Karpukhina, V.N. (2015). Literaturnye khronotopy: poetika, semiotika, perevod [Literary chronotopes: poetics, semiotics, translation]. Barnaul, IP Kolmogorov I.A., 171 p.

Krivousova, Z.G. (2014). Literaturnye siuzhety v "Detskoi knige" B. Akunina [Literary plots in the "Children's book" of Boris Akunin], In Siuzhetologiia i siuzhetografiia [Plot-studying and plotscripting], 2, 134-140.

Lotman, Yu.M. (2000). Semiosfera [Semiosphere]. St. Petersburg, Iskusstvo-SPB, 704 p.

Mironov, V.V. (2006). Kommunikatsionnoe prostranstvo kak factor transformatsii sovremennoi kul'tury i filosofii [Communication space as a factor of contemporary culture and philosophy transformation], In Voprosy filosofi [Issues of philosophy], 2, 27-43.

Ranchin, A. (2013). Postmodernistskoe puteshestvie v prostranstve i vremeni v romane Borisa Akunina "Altyn-tolobas" [Postmodernist travelling in time and space in the Boris Akunin's novel of "Altyn-tolobas"], In Pereklichka Kamen: Filologicheskie etudy [Cross-talk of Camenae: Philological essays]. Moscow, Novoe literaturnoe obozrenie, 588-598.

Snell-Hornby, M. (1988). Translation Studies: An Integrated Approach. Amsterdam, Philadelphia, John Benjamins Publishing Company, 163 p.

\title{
Многоязычное коммуникативное пространство текстов
} Бориса Акунина в переводе на английский язык

\author{
В.Н. Карпухина \\ Алтайский государственный университет \\ Россия, 656049, Барнаул, пр. Ленина, 61
}

\begin{abstract}
В статье рассматриваются проблемы изменения коммуникативного пространства в эпоху глобализации. Данные изменения представлены на примере анализа перевода постмодернистского художественного текста. Многоязычное коммуникативное пространство романа Бориса Акунина «Азазель», переведенного на английский язык Эндрю Бромфилдом, существенно отличается от коммуникативного пространства текста оригинала. Причиной возникновения отличий служит используемая переводчиком лингвоаксиологическая макростратегия адаптации. Макростратегия адаптации выявляет возможности варьирования при межъязыковой коммуникации семантической категории пространства (как текстового, так и культурного). Биполярность данной макростратегии (адаптация / остранение) обусловлена необходимостью для переводчика либо полной аккультурации текста оригинала в культуру языка перевода, либо, наоборот, достижения эффекта «инокультурности» переводимого текста. В результате действия макростратегии адаптации в тексте перевода не переданы некоторые функции многоязычного коммуникативного пространства текста оригинала. Английский язык, на котором говорят многие персонажи романа «Азазель», не показан в переводе как язык межнационального общения, своего рода lingua franca новой эпохи.
\end{abstract}

Ключевые слова: коммуникативное пространство, английский язык, русский язык, коммуникативный фрагмент, художественный текст, перевод.

Научная специальность: 10.00.00 - филологические науки. 